\title{
MODEL PARTISIPASI KONTRAKTOR SKALA KECIL DALAM PELELANGAN
}

\section{Small-Scale Contractor's Participation Model In Auction}

\author{
Alprido Perdian ${ }^{1}$, Eko Andi Suryo ${ }^{2}$, Indradi Wijatmiko ${ }^{3}$ \\ ${ }^{1,2,3}$ Program Magister Teknik Sipil Fakultas Teknik Universitas Brawijaya \\ Jl. MT Haryono 167, Malang 65145 - Telp. (0341) 567886 \\ Alamat korespondensi: \\ Email: alpridop@gmail.com
}

\begin{abstract}
Contractors have a consideration based on the internal and external conditions to participate in the auction. Contractor's qualified make consideration of participation in the auction to be different. The main problem is the ability of small - scale contractors is very limited, but has $90.66 \%$ of the total population of contractors registered in Construction Services Development Board. Based the reasons, we need to know the factors affecting, analysis of the variables that affect and how it affects the participation of small-scale contractors, also the contractor's participation model in auction. Questionnaires and interviews were conducted to 46 contractors in Palangkaraya. After the descriptive analysis, impact analysis and modeling conducted using Structural Equation Modelling - Partial Least Square ( SEM - PLS ) by software SmartPLS3. The analysis showed the factors that most influence the participation of small-scale contractors in the auction is "Have feasible Machine", " Project's Size and Complexity " and "Availability of Raw Materials Required". The result of impact analysis is Company's Ability, Project's Characteristic, Economic, Enviroment and Goverment Conditions significantly affect the participation of small scale contractors and established model:

$C P=0,327 C A+0,316 P C+0,312 E E G+0,200 \zeta$
\end{abstract}

Keyword: Contractor, Auction, SEM-PLS

\begin{abstract}
Abstrak
Kontraktor memiliki pertimbangan berdasarkan kondisi internal dan eksternal untuk berpartisipasi dalam pelelangan. Kualifikasi kontraktor membuat pertimbangan partisipasi kontraktor dalam pelelangan menjadi berbeda-beda. Permasalahan utama kontraktor kualifikasi usaha kecil adalah kemampuannya yang sangat terbatas, namun memiliki jumlah sebesar 90,66\% dari total populasi kontraktor yang terdaftar di LPJK. Berdasarkan alasan tersebut perlu diketahui faktor yang mempengaruhi, analisis variabel yang berpengaruh dan bagaimana pengaruhnya terhadap partisipasi kontraktor dan juga model partisipasi kontraktor dalam pelelangan. Survei kuesioner dan wawancara dilakukan kepada 46 kontraktor yang ada di Kota Palangkaraya. Setelah analisis deskriptif, analisis pengaruh dan pembuatan model dilakukan menggunakan Structure Equation Modelling - Partial Least Square (SEM-PLS) dengan bantuan software SmartPLS3. Hasil analisis menunjukkan bahwa faktor yang paling mempengaruhi partisipasi kontraktor kualifikasi usaha kecil dalam pelelangan, yaitu "Memiliki Peralatan Yang Memenuhi Syarat", "Ukuran Proyek dan Tingkat Kompleksitas" dan "Ketersediaan Bahan Baku Yang Disyaratkan". Untuk analisis pengaruh didapatkan bahwa kemampuan perusahaan, karakteristik proyek serta kondisi ekonomi, lingkungan dan pemerintah berpengaruh secara signifikan terhadap partisipasi kontraktor kualifikasi usaha kecil dan membentuk model: $\mathrm{PK}=0,327 \mathrm{KP}+$
\end{abstract}

0,316 KPro + 0,312 ELP + 0,200々

Kata kunci: Kontraktor, Pelelangan, SEM-PLS

\section{PENDAHULUAN}

Proses tender (pelelangan) merupakan langkah awal kontraktor untuk memperoleh proyek karena tanpa mengikuti proses pelelangan, kontraktor tidak akan bisa melakukan proses produksi. Kontraktor sebagai penyedia jasa tentunya memiliki pertimbangan tersendiri untuk ikut atau tidaknya di dalam kegiatan pelelangan. Pertimbangan tersebut didasarkan pada penguasaan yang baik terhadap berbagai situasi dan kondisi di lingkungan perusahaan (internal) dan pada proyek yang bersangkutan serta di lingkungan sosial masyarakat (eksternal). 
Perbedaan penggolongan kualifikasi kontraktor tentu turut membedakan pertimbangan-pertimbangan yang mendasari partisipasi keikutsertaan kontraktor dalam pelelangan. Pada umumnya kontraktor kualifikasi usaha kecil mengalami berbagai permasalahan dikarenakan kemampuan kontraktor kualifikasi usaha kecil sangat terbatas. Kontraktor harus dapat merencanakan partisipasi dalam sebuah lelang dengan baik agar dapat memperoleh jaminan profit atau keuntungan jika seandainya memenangkan lelang. Banyak kontraktor, terutama kontraktor kualifikasi usaha kecil yang kurang memahami hal ini sehingga tidak bisa menjaga keberlangsungan bisnis. Untuk itu kontraktor kualifikasi usaha kecil harus mengembangkan kemampuannya agar mampu mempertimbangkan partisipasi dalam pelelangan dengan baik dan mengutamakan kualitas, ketepatan waktu serta efisensi biaya. Terkait penjelasan di atas, maka dirasa perlu untuk mengetahui faktor yang mempengaruhi partisipasi kontraktor kualifikasi usaha kecil dalam pelelangan mengingat jumlah kontraktor kualifikasi usaha kecil sebanyak 90,66 \% dari total populasi kontraktor yang terdaftar di LPJK. Selain itu juga perlu dilakukan analisis mengenai variabel yang mempengaruhi dan bagaimana pengaruhnya terhadap partisipasi kontraktor, serta perlunya dibuat sebuah model partisipasi kontraktor dalam pelelangan sehingga dapat membantu kontraktor kualifikasi usaha kecil berpartisipasi dalam suatu pelelangan. Adapun tujuan yang ingin dicapai dalam penelitian ini adalah sebagai berikut:

- Memberikan informasi mengenai faktor yang mempengaruhi partisipasi kontraktor kualifikasi usaha kecil dalam pelelangan.

- Memberikan informasi mengenai variabel yang berpengaruh dan bagaimana pengaruhnya terhadap partisipasi kontraktor kualifikasi usaha kecil ( $\mathrm{K} 1, \mathrm{~K} 2$, K3).

- Mengetahui model partisipasi kontraktor skala kecil dalam pelelangan.

Batasan masalah dalam penelitian ini adalah:

- Penelitian dilakukan pada kontraktor kontraktor kualifikasi usaha kecil ( K1, K2, K3) yang berada di kota Palangka Raya yang telah berpartisipasi dalam pelelangan proyek konstruksi di Provinsi Kalimantan Tengah.

- Model dalam penelitian ini menggunakan Structural Equation Modeling - Partial Least Square (SEM-PLS)

\section{METODE PENELITIAN}

\section{Populasi dan Sampel}

Populasi dalam penelitian ini adalah kontraktor skala kecil di Palangka Raya. Pengambilan sampel yang dilakukan menggunakan Metode Random Sampling. Untuk jumlah sampel dalam penelitian ini berdasarkan jmlah sampel minimal untuk metode SEM-PLS yaitu 30-100 data. Menurut Chin (1998) dalam Latan \& Ghozali (2013), jumlah sampel dapat dihitung dengan cara sepuluh kali jumlah variabel endogen dalam model. Karena variabel endogen dalam penelitian ini hanya satu, maka yang digunakan adalah seluruh variabel baik eksogen dan endogen sehingga sampel yang digunakan dalam penelitian ini adalah minimal 40 sampel.

Tabel 1. Variabel Penelitian

\begin{tabular}{|c|c|}
\hline Variabel & Indikator \\
\hline $\begin{array}{l}\text { Kemampuan } \\
\text { Perusahaan } \\
\text { (KP) }\end{array}$ & $\begin{array}{l}\text { - Memiliki Tenaga Kerja Yang } \\
\text { Memenuhi Syarat (KP1) } \\
\text { - Tersedianya Pekerja (Lokal) } \\
\text { Yang Memenuhi Syarat (KP2) } \\
\text { - Pengalaman Keuntungan dan } \\
\text { Kegagalan Dari Proyek Sejenis } \\
\text { (KP3) } \\
\text { - Beban Kerja Saat Persiapan } \\
\text { Penawaran (KP4) } \\
\text { - Proporsi Pekerjaan Yang } \\
\text { disubkan (KP5) } \\
\text { - Hubungan dengan Pemilik } \\
\text { Proyek (KP6) } \\
\text { - Kemampuan Keuangan Saat } \\
\text { Penawaran (KP7) } \\
\text { - Hubungan Dengan Kontraktor } \\
\text { Lain dan Supplier (KP8) } \\
\text { - Memiliki Peralatan Yang } \\
\text { Memenuhi Syarat (KP9) } \\
\text { - Kemampuan Perusahaan } \\
\text { Dalam Persyaratan Teknik } \\
\text { Konstruksi Yang Disyaratkan } \\
\text { Direksi (KP10) } \\
\text { - Kepercayaan Diri Perusahaan } \\
\text { (KP11) }\end{array}$ \\
\hline
\end{tabular}


Lanjutan Tabel 1. Variabel Penelitian

\begin{tabular}{|c|c|}
\hline Variabel & Indikator \\
\hline $\begin{array}{c}\text { Karakteristik } \\
\text { Proyek (KPro) }\end{array}$ & $\begin{array}{l}\text { - Resiko Lokasi (KPro1) } \\
\text { - Tipe Proyek (KPro2) } \\
\text { - Ukuran Proyek dan Tingkat } \\
\text { - Kompleksitas (KPro3) } \\
\text { - Durasi Proyek (KPro4) } \\
\text { - Identitas Pemilik Proyek } \\
\text { - KPro5) } \\
\text { - Cara Pembayaran (KPro6) } \\
\text { - Ketentuan Jaminan (KPro7) } \\
\text { - Persyaratan Prakualifikasi } \\
\text { - } \text { (KPro8) } \\
\text { - Metode Penawaran } \\
\text { - (terbuka/tertutup) (KPro9) } \\
\text { - Waktu Yang Diberikan } \\
\text { - Untuk } \\
\text { - Persiapan Penawaran } \\
\text { - KPro10) } \\
\text { - Kelengkapan Gambar Kerja } \\
\text { - San } \\
\text { - Peesifikasi (KPro11) } \\
\text { - KPro12) } \\
\text { - Keketatan Spesifikasi } \\
\text { (KPro13) }\end{array}$ \\
\hline $\begin{array}{c}\text { Ekonomi, } \\
\text { Lingkungan } \\
\text { dan Pemerintah } \\
(\text { ELP) }\end{array}$ & $\begin{array}{ll}\text { - } & \text { Banyaknya Kompetitor } \\
& \text { (ELP1) } \\
\text { - } & \text { Fluktuasi Harga } \\
& \text { Sumberdaya (ELP2) } \\
\text { - } & \text { Kecukupan Informasi } \\
& \text { Harga Pasar (ELP3) } \\
\text { - } & \text { Keberatan Masyarakat } \\
& \text { (ELP4) } \\
\text { - } & \text { Ketersediaan Bahan Baku } \\
& \text { Yang Disyaratkan (ELP5) } \\
\text { - } & \text { Harga Dasar Yang } \\
& \text { Diperkirakan (ELP6) } \\
\text { - } & \text { Kebijakan Pemerintah } \\
& \text { (ELP7) } \\
\text { - } & \text { Musim (ELP8) } \\
\end{array}$ \\
\hline $\begin{array}{c}\text { Partisipasi } \\
\text { KOntraktor (Y) }\end{array}$ & $\begin{array}{l}\text { Kontraktor berpartisipasi } \\
\text { dalam lelang berdasarkan } \\
\text { perhitungan efisiensi biaya, } \\
\text { mengutamakan mutu dan } \\
\text { perhitungan ketepatan waktu. }\end{array}$ \\
\hline
\end{tabular}

\section{Analisis SEM-PLS}

Terdapat tiga model analisis jalur dalam PLS, yaitu inner model yang menspesifikasi hubungan antar variabel laten, outer model yang menspesifikasi hubungan antara variabel laten dengan variabel manifes, weight relation yang mengestimasi nilai dari variabel laten. Dalam evaluasi model pengukuran, dilakukan uji convergent validity, discriminant validity, composite reliability, dan Average Variance Extracted. Sedangkan dalam evaluasi model struktural dilakukan uji $\mathrm{R}$-squared $\left(\mathrm{R}^{2}\right)$ dan uji estimasi koefisien jalur.

- Convergent validity

Convergent validity digunakan untuk mengukur besarnya korelasi antara variabel laten dengan variabel manifes pada model pengukuran refleksif. Suatu kolerasi dapat dikatakan memenuhi convergent validity apabila memiliki nilai loading sebesar lebih besar dari 0,5 sampai 0,6 .

- Discriminant Validity

Discriminant validity dapat dikatakan tercapai apabila nilai AVE lebih besar dari 0,5 .

- Composite Reliability

Variabel laten dapat dikatakan memiliki realibilitas yang baik apabila nilai composite reliability lebih besar dari 0,6.

- $\mathrm{R}$-squared $\left(\mathrm{R}^{2}\right)$

Nilai R-squared $\left(\mathrm{R}^{2}\right)$ digunakan untuk menilai seberapa besar pengaruh variabel laten independen tertentu terhadap variabel laten dependen. Menurut Chin (1998) dalam Ghozali (2008), hasil $\mathrm{R}^{2}$ sebesar 0,67 mengindikasikan bahwa model dikategorikan baik. Hasil $\mathrm{R}^{2}$ sebesar 0,33 mengindikasikan bahwa model dikategorikan moderat. Sedangkan Hasil $\mathrm{R}^{2}$ sebesar 0,19 mengindikasikan bahwa model dikategorikan lemah.

- Uji Signifikansi

Uji signifikansi bertujuan untuk mengetahui seberapa besar pengaruh variabel bebas terhadap variabel terikat. Hipotesis yang digunakan pada uji signifikansi adalah:

$\mathrm{HO}=$ Variabel bebas tidak berpengaruh signifikan terhadap varabel terikat

$\mathrm{H} 1$ = Variabel bebas berbengaruh signifikan terhadap variabel terikat

\section{HASIL DAN PEMBAHASAN}

\section{Karakteristik Perusahaan}

Tabel 2. Kualifikasi Perusahaan

\begin{tabular}{cccc}
\hline No & Kualifikasi & Jumlah & $(\%)$ \\
\hline 1 & K1 & 10 & 21,74 \\
2 & K2 & 12 & 26,09 \\
3 & K3 & 24 & 52,17 \\
& Total & 46 & 100 \\
\hline
\end{tabular}


Tabel 3. Pengalaman Perusahaan

\begin{tabular}{cccc}
\hline No & Pengalaman & Jumlah & $(\%)$ \\
\hline 1 & $<5$ tahun & 14 & 30,43 \\
2 & $5-10$ tahun & 18 & 39,13 \\
3 & $10-15$ tahun & 6 & 13,04 \\
4 & $>15$ tahun & 8 & 17,39 \\
& Total & 46 & 100 \\
\hline
\end{tabular}

\section{Karakteristik Responden}

\begin{tabular}{|c|c|c|c|}
\hline No & Jenis Kelamin & Jumlah & $(\%)$ \\
\hline 1 & Pria & 35 & 76,09 \\
\hline 2 & Wanita & 11 & 23,91 \\
\hline & Total & 46 & 100 \\
\hline \multicolumn{4}{|c|}{ Tabel 5. Umur Responden } \\
\hline No & Umur Responden & Jumlah & $(\%)$ \\
\hline 1 & $<25$ tahun & 2 & 4,35 \\
\hline 2 & $25-35$ tahun & 15 & 32,61 \\
\hline 3 & 35 - 45 tahun & 17 & 36,96 \\
\hline 4 & $>45$ tahun & 12 & 26,09 \\
\hline & Total & 46 & 100 \\
\hline
\end{tabular}

Tabel 6. Pendidikan Terakhir Responden

\begin{tabular}{|c|c|c|c|}
\hline No & Pendidikan & Jumlah & (\%) \\
\hline 1 & SMA Sederajat & 19 & 41,30 \\
\hline 2 & D3/D4 & 3 & 6,52 \\
\hline 3 & S1 & 21 & 45,65 \\
\hline \multirow[t]{2}{*}{4} & S2 & 3 & 6,52 \\
\hline & Total & 46 & 100 \\
\hline
\end{tabular}

Tabel 7. Pengalaman Kerja Responden

\begin{tabular}{clcc}
\hline No & \multicolumn{1}{c}{ Pengalaman } & Jumlah & $(\%)$ \\
\hline 1 & $<5$ tahun & 19 & 41,30 \\
2 & $5-10$ tahun & 16 & 34,78 \\
3 & $10-15$ tahun & 4 & 8,70 \\
4 & $>15$ tahun & 7 & 15,22 \\
\multicolumn{2}{r}{ Total } & 46 & 100 \\
\hline
\end{tabular}

Tabel 8. Jabatan Responden

\begin{tabular}{clcc}
\hline No & \multicolumn{1}{c}{ Jabatan } & Jumlah & $(\%)$ \\
\hline 1 & Direktur & 46 & 100,00 \\
2 & Site Manager & 0 & 0,00 \\
3 & Staf Pelaksana Lap. & 0 & 0,00 \\
4 & Lainnya & 0 & 0,00 \\
& \multicolumn{1}{c}{ Total } & 46 & 100 \\
\hline
\end{tabular}

\section{Uji Validitas}

Uji validitas dalam penelitian ini dimaksudkan untuk mengetahui apakah kuesioner yang disiapkan telah dapat mengukur variabel yang ingin diukur. Uji validitas dilakukan pada masing-masing item pernyataan kuesioner dengan jalan menghitung corrected item-total correlation dari tiap-tiap pernyataan dengan skor total yang diperoleh. Kriterianya adalah jika nilai corrected item-total correlation lebih besar dari r-tabel maka item pertanyaan adalah valid. Dengan menggunakan distribusi (table $r$ ) untuk $\alpha=0,05$ dan jumlah responden sebanyak 46, sehingga didapat r-tabel $=0,291$. Rekapitulasi hasil uji validasi dengan bantuan SPSS 17 seperti pada tabel 9 .

Tabel 9. Rekapitulasi Hasil Uji Validasi

\begin{tabular}{clccc}
\hline No & $\begin{array}{c}\text { Kode } \\
\text { Indikator }\end{array}$ & Rtabel & Rhitung & Ket. \\
\hline 1 & KP1 & 0,291 & 0,721 & valid \\
2 & KP2 & 0,291 & 0,570 & valid \\
3 & KP3 & 0,291 & 0,831 & valid \\
4 & KP4 & 0,291 & 0,545 & valid \\
5 & KP5 & 0,291 & 0,614 & valid \\
6 & KP6 & 0,291 & 0,681 & valid \\
7 & KP7 & 0,291 & 0,741 & valid \\
8 & KP8 & 0,291 & 0,785 & valid \\
9 & KP9 & 0,291 & 0,809 & valid \\
10 & KP10 & 0,291 & 0,792 & valid \\
11 & KP11 & 0,291 & 0,690 & valid \\
12 & KPro1 & 0,291 & 0,781 & valid \\
13 & KPro2 & 0,291 & 0,785 & valid \\
14 & KPro3 & 0,291 & 0,903 & valid \\
15 & KPro4 & 0,291 & 0,760 & valid \\
16 & KPro5 & 0,291 & 0,673 & valid \\
17 & KPro6 & 0,291 & 0,517 & valid \\
18 & KPro7 & 0,291 & 0,441 & valid \\
19 & KPro8 & 0,291 & 0,816 & valid \\
20 & KPro9 & 0,291 & 0,603 & valid \\
21 & KPro10 & 0,291 & 0,710 & valid \\
22 & KPro11 & 0,291 & 0,858 & valid \\
23 & KPro12 & 0,291 & 0,833 & valid \\
24 & KPro13 & 0,291 & 0,738 & valid \\
25 & ELP1 & 0,291 & 0,659 & valid \\
26 & ELP2 & 0,291 & 0,590 & valid \\
27 & ELP3 & 0,291 & 0,452 & valid \\
28 & ELP4 & 0,291 & 0,582 & valid \\
29 & ELP5 & 0,291 & 0,758 & valid \\
30 & ELP6 & 0,291 & 0,587 & valid \\
31 & ELP7 & 0,291 & 0,713 & valid \\
32 & ELP8 & 0,291 & 0,466 & valid \\
33 & Y & 0,291 & 0,874 & valid \\
\hline & & & &
\end{tabular}




\section{Uji Model Pengukuran (Outer Model)}

Sebelum melakukan pengujian hipotesis yang memprediksi hubungan relasional dalam model struktural, pengujian model pengukuran harus dilakukan terlebih dahulu untuk verifikasi indikator dan variabel laten yang dapat diuji selanjutnya. Pengujian tersebut meliputi pengujian validitas konstruk (konvergen dan diskriminan).

Pengujian validitas untuk indikator reflektif menggunakan korelasi antara skor item dengan skor konstruknya. Indikator dieliminasi dari model jika tidak memenuhi nilai loading faktor yang ditetapkan dalam standar uji validitas konstruk sebesar 0,7. Indikator yang dieliminasi dari permodelan merupakan indikator yang memiliki nilai loading faktor terendah. Setelah indikator yang tidak valid tersebut dieliminasi, maka dilakukan pengujian berulang sehingga mendapatkan model yang berisi indikator yang valid seluruhnya.

Setelah melakukan 12 kali modifikasi model, nilai outer loading pada indikator secara keseluruhan telah melebihi 0,7. Untuk indikator yang valid dan tidak valid pada uji model pengukuran dapat dilihat pada tabel 10 dan tabel 11 berikut.

Tabel 10. Rekapitulasi Indikator Yang Valid

\begin{tabular}{clcc}
\hline No. & \multicolumn{1}{c}{ Indikator } & Kode & $\begin{array}{c}\text { Nilai Outer } \\
\text { Loading }\end{array}$ \\
\hline 1 & $\begin{array}{l}\text { Memiliki Tenaga Kerja Yang } \\
\text { Memenuhi Syarat }\end{array}$ & KP1 & 0.820 \\
2 & $\begin{array}{l}\text { Pengalaman Keuntungan dan } \\
\text { Kegagalan Dari Proyek Sejenis }\end{array}$ & KP3 & 0.868 \\
3 & $\begin{array}{l}\text { Hubungan Dengan Pemilik } \\
\text { Proyek }\end{array}$ & KP6 & 0.711 \\
4 & $\begin{array}{l}\text { Kemampuan Keuangan Saat } \\
\text { Penawaran }\end{array}$ & KP7 & 0.798 \\
5 & $\begin{array}{l}\text { Hubungan Dengan Kontraktor } \\
\text { Lain dan Supplier }\end{array}$ & KP8 & 0.768 \\
6 & $\begin{array}{l}\text { Memiliki Peralatan Yang } \\
\text { Memenuhi Syarat }\end{array}$ & KP9 & 0.890 \\
7 & $\begin{array}{l}\text { Kemampuan Perusahaan Dalam } \\
\text { Persyaratan Teknik Konstruksi }\end{array}$ & KP10 & 0.877 \\
Yang Disyaratkan Direksi & KP11 & 0.787 \\
8 & $\begin{array}{l}\text { Kepercayaan Diri Perusahaan } \\
\text { Resiko Lokasi }\end{array}$ & KPro1 & 0.842 \\
10 & $\begin{array}{l}\text { Tipe Proyek } \\
\text { Ukuran Proyek dan Tingkat } \\
\text { Kompleksitas }\end{array}$ & KPro2 & 0.820 \\
\hline Sumber: Hasil Rekap Analisis Data, 2016 & 0.914 \\
\hline
\end{tabular}

Sumber: Hasil Rekap Analisis Data, 2016
Lanjutan Tabel 9. Rekapitulasi Indikator

$$
\text { Yang Valid }
$$

\begin{tabular}{|c|c|c|c|}
\hline No. & Indikator & Kode & $\begin{array}{c}\text { Nilai Outer } \\
\text { Loading }\end{array}$ \\
\hline 12 & Durasi Proyek & KPro4 & 0.737 \\
\hline 13 & Identitas Pemilik Proyek & KPro5 & 0.792 \\
\hline 14 & Persyaratan Prakualifikasi & KPro8 & 0.892 \\
\hline 15 & $\begin{array}{l}\text { Waktu Yang Diberikan Untuk } \\
\text { Persiapan Penawaran }\end{array}$ & KPro10 & 0.840 \\
\hline 16 & $\begin{array}{l}\text { Kelengkapan Gambar Kerja dan } \\
\text { Spesifikasi }\end{array}$ & KPro11 & 0.891 \\
\hline 17 & Peraturan/ketentuan & KPro12 & 0.853 \\
\hline 18 & Keketatan Spesifikasi & KPro13 & 0.853 \\
\hline 19 & $\begin{array}{l}\text { Ketersediaan Bahan Baku Yang } \\
\text { Disyaratkan }\end{array}$ & ELP5 & 0.935 \\
\hline 20 & Kebijakan Pemerintah & ELP7 & 0.931 \\
\hline 21 & $\begin{array}{l}\text { Kontraktor berpartisipasi dalam } \\
\text { lelang berdasarkan perhitungan } \\
\text { efisiensi biaya, mengutamakan } \\
\text { mutu dan perhitungan ketepatan } \\
\text { waktu. }\end{array}$ & $\mathrm{Y}$ & 1.000 \\
\hline
\end{tabular}

Tabel 11. Rekapitulasi Indikator Yang Tidak

\begin{tabular}{|c|c|c|c|}
\hline \multicolumn{4}{|c|}{ Valid } \\
\hline No. & Indikator & Kode & $\begin{array}{l}\text { Nilai Outer } \\
\text { Loading }\end{array}$ \\
\hline 1 & Ketentuan Jaminan & KPro7 & 0.351 \\
\hline 2 & Cara Pembayaran & KPro6 & 0.327 \\
\hline 3 & $\begin{array}{l}\text { Tersedianya Pekerja } \\
\text { (Lokal) Yang Memenuhi } \\
\text { Syarat }\end{array}$ & KP2 & 0.569 \\
\hline 4 & $\begin{array}{l}\text { Beban Kerja Saat } \\
\text { Persiapan Penawaran }\end{array}$ & KP4 & 0.569 \\
\hline 5 & Banyaknya Kompetitor & ELP1 & 0.577 \\
\hline 6 & $\begin{array}{l}\text { Kecukupan Informasi } \\
\text { Harga Pasar }\end{array}$ & ELP3 & 0.543 \\
\hline 7 & $\begin{array}{l}\text { Metode Penawaran } \\
\text { (terbuka/tertutup) }\end{array}$ & KPro9 & 0.582 \\
\hline 8 & $\begin{array}{l}\text { Harga Dasar Yang } \\
\text { Diperkirakan }\end{array}$ & ELP6 & 0.661 \\
\hline 9 & Musim & ELP8 & 0.670 \\
\hline 10 & $\begin{array}{l}\text { Fluktuasi Harga } \\
\text { Sumberdaya }\end{array}$ & ELP2 & 0.627 \\
\hline 11 & $\begin{array}{l}\text { Proporsi Pekerjaan Yang } \\
\text { disubkan }\end{array}$ & KP5 & 0.670 \\
\hline 12 & Keberatan Masyarakat & ELP4 & 0.678 \\
\hline
\end{tabular}


Selanjutnya reliabilitas konstruk diukur dengan Composite Reliability dan Cronbach Alpha. Konstruk dikatakan reliabel jika memiliki nilai Composite Reliability dan Cronbach Alpha di atas 0.70 (Ghozali (2008). Hasil pengujian reliabilitas menyatakan bahwa konstruk dalam penelitian ini mempunyai reabilitas yang cukup baik atau mampu untuk mengukur konstruknya karena memenuhi nilai Composite Reliability dan Cronbach Alpha. Hasilnya dapat dilihat pada Gambar 3 dan Gambar 4.

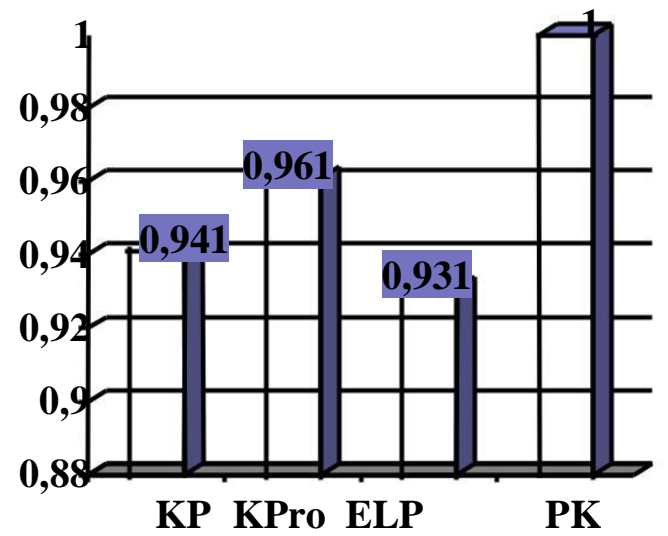

Gambar 3. Nilai Composite Reliability

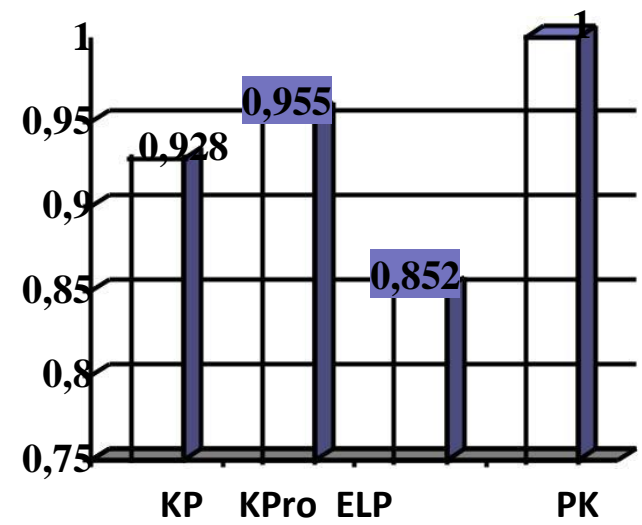

Gambar 4. Nilai Cronbach's Alpha

\section{Analisis Deskriptif}

Analisis data menggunakan statistik deskriptif, dengan mencari nilai mean dan varian untuk mentukan kategori dan variasi jawaban responden terhadap kuesioner yang telah diisi, dan juga memberi peringkat dari faktor-faktor partisipasi kontraktor dalam pelelangan untuk memberikan gambaran atau penjelasan dari hasil penelitian.

Dari delapan pernyataan berdasarkan hasil analisis pada tabel 12, menunjukkan bahwa kode KP7 dengan pernyataan "Kemampuan Keuangan Saat Penawaran" menjadi peringkat pertama dalam konstruksi.
Kemampuan Perusahaan dengan nilai mean 4,609 dan nilai varian 0,421 . Hasil ini juga diperkuat dengan hasil penelitian yang dilakukan Sawitri,dkk (2006), Suciptapura, dkk (2013) dan Ariyato (2011) yang menyimpulkan bahwa "Kemampuan Keuangan Saat Penawaran" menjadi salah satu faktor utama dalam keputusan melakukan penawaran.

Tabel 12. Peringkat Indikator Konstruk Kemampuan Perusahaan

\begin{tabular}{cccc}
\hline Kode & Mean & Varian & Peringkat \\
\hline KP7 & 4,609 & 0,421 & $\begin{array}{c}\text { Sangat } \\
\text { Menentukan }\end{array}$ \\
KP10 & 4,478 & 0,477 & Menentukan \\
KP1 & 4,413 & 0,381 & Menentukan \\
KP9 & 4,348 & 0,676 & Menentukan \\
KP3 & 4,304 & 0,750 & Menentukan \\
KP11 & 4,283 & 0,385 & Menentukan \\
KP6 & 4,174 & 0,725 & Menentukan \\
KP8 & 4,174 & 0,725 & Menentukan \\
\hline
\end{tabular}

Dari sepuluh pernyataan berdasarkan hasil analisis pada tabel 13, menunjukkan bahwa kode Kpro4 dengan pernyataan "Durasi Proyek" menjadi peringkat pertama dalam konstruk Karakteristik Proyek dengan nilai mean 4,478 dan nilai varian 0,388 . Hasil ini juga diperkuat dengan hasil penelitian yang dilakukan Suciptapura,dkk (2013) dan Respawan (2015) yang menyimpulkan bahwa "Durasi Proyek" menjadi salah satu faktor utama dalam keputusan melakukan penawaran.

Tabel 13. Peringkat Indikator Konstruk Karakteristik Proyek

\begin{tabular}{cccc}
\hline Kode & Mean & Varian & Kategori \\
\hline KPro4 & 4,478 & 0,388 & Menentukan \\
KPro3 & 4,348 & 0,499 & Menentukan \\
KPro11 & 4,283 & 0,696 & Menentukan \\
KPro12 & 4,261 & 0,730 & Menentukan \\
KPro2 & 4,217 & 0,663 & Menentukan \\
KPro13 & 4,196 & 0,428 & Menentukan \\
KPro8 & 4,174 & 0,414 & Menentukan \\
KPro10 & 3,957 & 0,798 & Menentukan \\
KPro5 & 3,891 & 0,721 & Menentukan \\
KPro1 & 3,761 & 0,897 & Menentukan \\
\hline
\end{tabular}


Selanjutnya Dari dua pernyataan berdasarkan hasil analisis pada tabel 14, menunjukkan bahwa kode ELP5 dengan pernyataan "Ketersediaan Bahan Baku Yang Disyaratkan" menjadi peringkat pertama dalam konstruk Ekonomi, lingkungan dan Pemerintah dengan nilai mean 4,435 dan nilai varian 0,429 .

Tabel 14. Peringkat Indikator Konstruk Ekonomi, Lingkungan, Pemerintah

\begin{tabular}{cccc}
\hline Kode & Mean & Varian & Kategori \\
\hline ELP5 & 4,435 & 0,429 & Menentukan \\
ELP7 & 4,283 & 0,429 & Menentukan \\
\hline
\end{tabular}

\section{Konversi Diagram Jalur}

- Persamaan Variabel Kemampuan Perusahaan

Dalam model penelitian ini, Variabel Kemampuan Perusahaan dibentuk oleh delapan indikator dengan nilai outer loading tertinggi 0,890 yang dimiliki oleh KP9 "Memiliki Peralatan Yang Memenuhi Syarat" dan merupakan indikator yang memiliki pengaruh paling besar pada kemampuan perusahaan. Hasil penelitian ini didukung oleh hasil penelitian Suciptapura, dkk (2013) dan Birama (2011) yang juga menyimpulkan bahwa "Memiliki Peralatan Yang Memenuhi Syarat" menjadi salah satu faktor utama yang mempengaruhi kontraktor mengikuti pelelangan.

Persamaan untuk Variabel Kemampuan Perusahaan yaitu:

$$
\begin{aligned}
\mathrm{KP}= & 0,820 \mathrm{KP} 1+0,868 \mathrm{KP} 6+0,711 \mathrm{KP} 6 \\
& +0,798 \mathrm{KP} 7+0,768 \mathrm{KP} 8+ \\
& 0,890 \mathrm{KP} 9+0,877 \mathrm{KP} 10+ \\
& 0,787 \mathrm{KP} 11
\end{aligned}
$$

- Persamaan Variabel Karakteristik Proyek Dalam model penelitian ini, Variabel Karakteristik Proyek dibentuk oleh sepuluh indikator dengan nilai outer loading tertinggi 0,914 yang dimiliki oleh KPro3 "Ukuran Proyek dan Tingkat Kompleksitas" dan merupakan indikator yang memiliki pengaruh paling besar pada karakteristik proyek.

Persamaan untuk Variabel Karakteristik Proyek yaitu:

$$
\begin{gathered}
\text { KPro }=0,842 \mathrm{KPro} 1+0,820 \mathrm{KPro} 2+ \\
\text { 0,914 KPro3 + 0,737KPro } 4+ \\
\text { 0,792KPro5 }+
\end{gathered}
$$

$$
\begin{aligned}
& \text { 0,892KPro } 8+0,840 \mathrm{KPro} 10+ \\
& \text { 0,891KPro } 11+0,853 \mathrm{KPro} 12+ \\
& \text { 0.853KPro13 }
\end{aligned}
$$

- Persamaan Variabel Ekonomi,

Lingkungan dan Pemerintah

Dalam model penelitian ini, Variabel

Karakteristik Proyek dibentuk oleh dua indikator dengan nilai outer loading tertinggi 0,935 yang dimiliki oleh ELP5 "Ketersediaan Bahan Baku Yang Disyaratkan" dan merupakan indikator yang memiliki pengaruh paling besar pada variabel kondisi ekonomi, lingkungan dan pemerintah.

Persamaan untuk Variabel Ekonomi,

Lingkungan dan Pemerintah yaitu: ELP = 0,935ELP5 + 0,931ELP7

Berdasarkan hasil perhitungan nilai mean dan nilai outer loading terdapat perbedaan ranking indikator yang paling berpengaruh dalam model yang disebabkan perhitungan nilai mean adalah perhitungan statistik yang digunakan untuk analisis data dengan cara mendeskripsikan atau menggambarkan data yang telah terkumpul sebagaimana adanya tanpa ada tujuan membuat kesimpulan. Sedangkan untuk nilai outer loading berasal

dari perhitungan statistik inferensial berdasarkan metode Partial Least Square yang bertujuan untuk pengujian hipotesis dan taraf signifikansi. Hal inilah yang menyebabkan perbedaan ranking dalam indikator.

\section{Evaluasi Model Struktural (Inner Model) Estimasi Koefisien Jalur}

Adapun model struktural dapat dievaluasi dengan melihat nilai koefisien parameter jalur (path coeficient parameter) dan $\mathrm{R}^{2}$ pada variabel endogen. Berikut hipotesis yang diangkat dalam penelitian ini adalah :

H1 : Kemampuan Perusahaan berpengaruh terhadap Partisipasi Kontraktor.

H2 : Kemampuan Perusahaan berpengaruh terhadap Partisipasi Kontraktor.

H3 : Ekonomi, Lingkungan dan Pemerintah berpengaruh terhadap Partisipasi Kontraktor.

Untuk tingkat keyakinan sebesar 95\%, maka hipotesis 1 ekor ( one tailed ) adalah > 1,64. 
Tabel 15. Hasil Rekapitulasi Model Struktural

\begin{tabular}{lcc} 
& $\begin{array}{c}\text { Struktural } \\
\text { Original } \\
\text { Sample (O) }\end{array}$ & T Statistics \\
\hline ELP -> PK & 0,312 & 1,904 \\
KP -> PK & 0,327 & 1,900 \\
KPro -> PK & 0,316 & 1,662 \\
\hline
\end{tabular}

Pengaruh hubungan variabel laten eksogen terhadap variabel laten endogen (Partisipasi Kontraktor) pada tabel diatas dapat dijelaskan sebagai berikut :

- Koefisien parameter jalur yang diperoleh dari hubungan antara variabel Kemampuan Perusahaan dengan Partisipasi Kontraktor sebesar 0,327 dengan nilai positif menunjukan tingginya kemampuan perusahaan maka akan meningkatkan partisipasi kontraktor. Selanjutnya dari Tabel 14 diperoleh nilai T-statistik $1,900>1,64$ pada taraf signifikansi $\alpha=0,05(5 \%)$ menyatakan bahwa terdapat Kemampuan Perusahaan berpengaruh signifikan terhadap Partisipasi Kontraktor yang berarti hipotesis H1 diterima. Nilai positif pada koefisien parameter artinya adalah semakin baik Kemampuan Perusahaan maka pengukur Partisipasi Kontraktror yaitu partisipasi kontraktor yang berdasarkan mutu, waktu dan biaya akan semakin tinggi.

- Koefisien parameter jalur yang diperoleh dari hubungan antara variabel Karakteristik Proyek dengan Partisipasi Kontraktor sebesar 0,316 dengan nilai positif menunjukan semakin tinggi penguasaan kontraktor terhadap karakteristik proyek maka akan semakin meningkatkan partisipasi kontraktor dalam pelelangan. Selanjutnya dari Tabel 14 diperoleh nilai T-statistik 1,662>1,64 pada taraf signifikansi $\alpha=0,05 \quad(5 \%)$ yang menyatakan bahwa terdapat pengaruh yang signifikan antara Karakteristik Proyek dengan Partisipasi Kontraktor dan berarti hipotesis H2 diterima

- Koefisien parameter jalur yang diperoleh dari hubungan antara variabel Ekonomi, Lingkungan dan Pemerintah dengan Partisipasi Kontraktor sebesar 0,312 dengan nilai positif menunjukan semakin tinggi penguasaan kontraktor terhadap kondisi Ekonomi, Lingkungan dan Pemerintah maka akan semakin meningkatkan partisipasi kontraktor dalam pelelangan. Selanjutnya dari Tabel 14 diperoleh nilai T-statistik 1,904 > 1,64 pada taraf signifikansi $\alpha=0,05(5 \%)$ yang menyatakan bahwa terdapat terdapat pengaruh yang signifikan antara Kondisi Ekonomi, Lingkungan dan Pemerintah dengan Partisipasi Kontraktor dan berarti hipotesis $\mathrm{H} 3$ diterima.

\section{R-squared $\left(\mathbf{R}^{2}\right)$}

Nilai $\mathrm{R}^{2}$ menunjukkan koefisien determinasi, sejauh mana suatu konstruk mampu menjelaskan model. Dari hasil model persamaan diatas diperoleh nilai $\mathrm{R}^{2}$ untuk variabel Partisipasi Kontraktor sebesar 0,800, yang diperoleh dari hasil analisis PLS dan dapat dilihat pada Gambar 2. Hasil Modifikasi ke-12 Konstruksi Diagram Jalur Permodelan PLS yang artinya nilai tersebut mengindikasikan bahwa variasi Partisipasi Kontraktor dapat dijelaskan oleh variabel

konstruk (Kemampuan Perusahaan, Karakteristik Proyek, serta Ekonomi, Lingkungan dan Pemerintah) sebesar $80 \%$. Sedangkan sisanya yaitu sebesar 0,200 (20\%) dipengaruhi oleh variabel lain yang tidak terdapat dalam model penelitian ini dan didefinisikan sebagai tingkat kesalahan struktural.

Menurut Chin (1998) dalam Jogiyanto dan Willy (2009), kriteria batasan nilai Rsquare dalam tiga klasifikasi, yaitu 0,67 (kuat), 0,33 (moderat), dan 0,19 (lemah). Hal ini berarti kebaikan pembentukan model dari Partisipasi Kontraktor dalam pelelangan dapat di jelaskan dengan kuat oleh variabel

Kemampuan Perusahaan, Karakteristik Proyek, serta Ekonomi, Lingkungan dan Pemerintah dengan nilai 0,800 (80\%).

Berdasarkan koefisien-koefisien parameter jalur yang diperoleh pada Tabel 14, maka model persamaan struktural yang terbentuk adalah sebagai berikut :

$\mathrm{PK}=0,327 \mathrm{KP}+0,316 \mathrm{KPro}+0,312 \mathrm{ELP}+$ $0,200 \zeta$

Keterangan:

PK = Partisipasi Kontraktor

$\mathrm{KP}=$ Kemampuan Perusahaan

KPro = Karakteristik Proyek

ELP = Kondisi Ekonomi, Lingkungan dan Pemerintah 
$\zeta \quad=$ Tingkat kesalahan struktural

Dari model tersebut dapat dilihat bahwa ketiga variabel memiliki nilai koefisien yang tidak jauh berbeda, menandakan bahwa ketiganya memiliki pengaruh yang kurang lebih sama dalam menentukan partisipasi kontraktor dalam pelelangan.

\section{KESIMPULAN DAN SARAN}

\section{Kesimpulan}

- Faktor yang mempengaruhi partisipasi kontraktor kualifikasi usaha kecil (K1, $\mathrm{K} 2$, K3) dalam pelelangan tender (pelelangan) yaitu:

- "Memiliki Peralatan Yang Memenuhi Syarat" pada Variabel Kemampuan Perusahaan dengan nilai outer loading sebesar 0,890 .

- "Ukuran Proyek dan Tingkat Kompleksitas" pada Variabel Karakteristik Proyek dengan nilai outer loading sebesar 0,914.

- "Ketersediaan Bahan Baku Yang Disyaratkan" pada Variabel Ekonomi, Lingkungan dan Pemerintah dengan nilai outer loading dengan nilai 0,935 .

- Kemampuan Perusahaan berpengaruh secara signifikan terhadap Partisipasi Kontraktor dengan nilai signifikasi sebesar 1,900, Karakteristik Proyek berpengaruh secara signifikan terhadap Partisipasi Kontraktor dengan nilai signifikasi sebesar 1,662, dan Kondisi Ekonomi, Lingkungan dan Pemerintah berpengaruh secara signifikan terhadap Partisipasi Kontraktor dengan nilai signifikasi sebesar 1,904.

- 3. Model Partisipasi Kontraktor Dalam Pelelangan dapat di jelaskan dengan kuat oleh variabel Kemampuan Perusahaan, Karakteristik Proyek, serta Ekonomi, Lingkungan dan Pemerintah sebesar $80 \%$. Model persamaan yang terbentuk dalam Model Partisipasi Kontraktor Dalam Pelelangan yaitu:

$\mathrm{PK}=0,327 \mathrm{KP}+0,316 \mathrm{KPro}+0,312 \mathrm{ELP}+$ $0,200 \zeta$

\section{Saran}

Masih ada faktor lain diluar model yang tidak bisa dijelaskan dalam penelitian ini. Saran yang dapat diberikan untuk penelitian selanjutnya yaitu mengembangkan lagi model dengan menggali lebih luas variabel lain yang dapat berpengaruh terhadap partisipasi kontraktor dalam pelelangan sehingga diperoleh variabelvariabel yang dapat menjelaskan model lebih dari $80 \%$.

\section{DAFTAR PUSTAKA}

Aibinu, A.A. dan Al-Lawati, A.M. 2010. Using PLS-SEM Technique To Model

Construction Organizations' Willingness To Participate In EBidding. Elsevier: Automation in Construction.

Ariyanto, Chandra. 2011. Faktor-Faktor Yang Mempengaruhi Kontraktor Dalam Mengikuti Tender Pemerintah. Surabaya: Institut Teknologi Sepuluh November.

Asnudin, A. 2005. Konsep Pengembangan Kontraktor Skala Kecil. Jurnal SMARTek Vol3, No 4.

Birama, R.D.A. 2011. Studi Mengenai Faktor - Faktor Yang Mempengaruhi Kontraktor Mengikuti Tender.

Yogyakarta: Universitas Atma Jaya.

Darliansyah, Iwan. 2008. Identifikasi Faktor Dominan Yang Berpengaruh Pada Kegagalan Memenangkan Tender Dengan Pendekatan Manajemen Resiko. Jakarta: Universitas Indonesia.

Ervianto, I.W. 2005. Manajemen Proyek Konstruksi. Yogyakarta: Andi.

Ghozali, Imam. 2008. Structural Equation Modeling, Metode Alternatif dengan Partial Least Square Edisi 2. Semarang: Badan Penerbit Universitas Diponegoro.

Hartono, J. 2011. Konsep dan Aplikasi Structural Equation Model Berbasis Varian Dalam Penelitian Bisnis. Yogyakarta: UPP STIM YKPN.

Hidayat, N. 2012. Pemodelan Structural Equation Modeling (SEM) Berbasis Varians Pada Derajat Kesehatan Di Propinsi Jawa Timur 2010. Yogyakarta: Universitas Negeri Yogyakarta.

Jogiyanto, H.M dan Willy, A. 2009. Konsep dan Aplikasi PLS (Partial Least Square) Untuk Penelitian Empiris. 
Yogyakarta: BPFE Fakultas

Ekonomika dan Bisnis UGM.

Latan, H. dan Ghozali, I. 2013. Partial Least Square, Konsep Aplikasi Path Modelling XLSTAT. Semarang: Badan Penerbit Universitas Diponegoro.

Respawan, M. 2015 Analisis Faktor Yang

Mempengaruhi Partisipasi Dan Nilai

Penawaran Peserta Lelang Elektronik

(E-Procurement) Jasa Konstruksi Di

Kabupaten Buleleng Denpasar:

Universitas Udayana.

Santoso, A.T. 2007. Peran Tim

Tender Dalam Usaha Peraihan Nilai

Kontrak Pada Perusahaan Jasa

Konstruksi. Jakarta: Universitas Indonesia.

Sawitri, M., Anwar, N. \& Adi, T.J.W. 2006.

Model Pengambilan Keputusan

Keikutsertaan Kontraktor Dalam

Tender Poroyek Konstruksi di Jawa

Timur. Surabaya: Prosiding Seminar Nasional Manajemen Teknologi IV.

Solimun. 2010. AnalisisMultivariat

Pemodelan Struktural Metode PLS. Malang: Citra Malang.

Suciptapura, I M., Putera, G A A. \&

Nadiasa,M. 2013. Partisipasi

Kontraktor di Kota Denpasar Dalam

Lelang Pengadaan Barang dan Jasa

Pemerintah Secara Elektronik.

Denpasar: Universitas Udayana.

Sugiyono. 2007. Metode Penelitian Administrasi. Bandung: Alfabeta.

Sugiyono. 2009. Metode Penelitian

Kuantitatif, Kualitatif, dan $R \& D$. Bandung: Alfabeta.

Surya, I.N. Iwan. 2011. Pengaruh Kualifikasi

Kontraktor Terhadap Kualitas

Pekerjaan Proyek Konstruksi Di

Kabupaten Jembrana. Denpasar:

Universitas Udayana.

Wibowo, M.A., Astana, I.N.Y., Rusdi,H.A.2015. An Analysis of Bidding Strategy, Project Performance And Company Performance Relationship In Construction. Elsevier: The 5th International Conference of Euro Asia Civil Engineering Forum.

Willy, A. Dan Jogiyanto, H.M. 2015. Partial Least Square (PLS) Alternatif Structural Equation Modeling (SEM) Dalam Penelitian Bisnis. Yogyakarta: Andi. 